\title{
Pemberian Lidocain-Ketorolac sebagai Analgesi Lokal Infiltrasi dibandingkan dengan Parasetamol Intravena untuk Manajemen Nyeri Pascaoperasi Seksio Sesarea (SC) di RSUD Mgr. Gabriel Manek, SVD Atambua
}

\author{
Yanti Permatasari, Willy Yant Kartolo \\ Departemen Anestesiologi dan Terapi Intesif RSUD Mgr. Gabriel Manek, SVD Atambua \\ Nusa Tenggara Timur
}

\begin{abstract}
Abstrak
Latar Belakang: Local Infiltration Analgesia (LIA) adalah teknik memberikan obat anestesi lokal yang diencerkan, dan diberikan adjuvant obat seperti anti-inflamasi nonsteroid (AINS), epinefrin, dan opioid. Tujuan: Untuk mengetahui apakah teknik LIA dapat menurunkan visual analoque scale (VAS) dan menurunkan kebutuhan analgetika dibandingkan pemberian parasetamol intravena dalam 24 jam pascaoperasi seksio sesarea(SC). Metode: Desain penelitian dengan studi intervensi pada populasi pasien wanita hamil yang akan dilakukan SC, dibagi dua kelompok yaitu menggunakan teknik LIA dan Parasetamol.

Hasil: Chi-Square pada jam ke-0 menunjukkan nilai sebesar 3.354 , dengan nilai $\mathrm{p}=0,340 \geq \alpha 0,05$, artinya pemberian parasetamol dan LIA belum memberikan pengaruh bermakna terhadap skala VAS, sedangkan pada uji Chi-Square jam ke-24 menunjukkan nilai sebesar 36.863, dengan nilai $\mathrm{p}=0,000 \leq \alpha 0,05$ memberikan pengaruh bermakna terhadap skala VAS pasien. Uji spearman pada jam ke-0 nilai koefisien korelasi sebesar -0.090 dengan nilai $p=0.459 \geq \alpha 0.05$ disimpulkan tidak ada hubungan yang signifikan pemberian parasetamol dan LIA dengan skala VAS. Uji Spearman jam ke-24 menunjukkan ada hubungan bermakna antara pemberian parasetamol dan LIA dengan skala VAS dengan nilai koefisien korelasi sebesar -0.671 nilai $p=0.000 \geq \alpha 0$ Simpulan: Pemberian LIA dapat menurunkan VAS dalam 24 jam pasca operasi SC dibandingkan dengan pemberian paracetamol intravena dan dapat mengurangi kebutuhan analgetik dalam 24 jam pasca-operasi SC dibandingkan dengan pemberian paracetamol intravena.
\end{abstract}

Kata kunci: analgesi lokal infiltrasi; lidokain-ketorola; parasetamol intravena; teknik LIA; VAS

\section{Lidocain-Ketorolac as Local Infiltration Analgesi Compared to Intravenous Paracetamol for Management Postoperative Pain in Caesarean Section in RSUD Mgr. Gabriel Manek, SVD Atambua}

\begin{abstract}
Background: LIA (Local Infiltration Analgesia) is a technique that provides localized anesthetic drugs that are diluted, and given adjuvants drugs such as NSAIDs, epinephrine, and opioids.

Objective: This study aims to determine the technique of LIA can decrease VAS and decrease analgesic requirements compared to intravenous administration of paracetamol within 24 hours postoperative SC.

Method. The design of this study used an intervention study with a population of pregnant women which have been done by SC and divided into two group which use technique of LIA and paracetamol.

Result:Chi-Square at hour 0 show value equal to 3,354, with value $p=0,340 \geq \alpha 0.05$, which mean giving paracetamol and LIA have not significant influence to VAS scale, while in Chi-Square test 24 hour show the value of 36.863 , with the value $p=0.000 \leq \alpha 0.05$ which means to provide a significant effect on the VAS scale of patients. In spearman test at hour 0 shows the value of correlation coefficient of -0.090 with $p=0.459 \geq \alpha 0.05$ there is no significant relationship giving paracetamol and LIA with VAS scale. Spearman correlation test clock 24 indicate there is significant relation between giving of paracetamol and LIA with scale of VAS have value of correlation coefficient equal to -0.671 with value $\mathrm{p}=0.000 \geq \alpha 0$.

Conclusion: . LIA reduced VAS in 24 hours after SC procedure better than intravenous Paracetamol and decreased analgetic consumption in 24 hours after SC procedure than intravenous Paracetamol.
\end{abstract}

Key words: local analgesia infiltration; lidocaine-ketorolac; LIA technique; VAS; intravenous paracetamol 


\section{Pendahuluan}

Tindakan pembedahan mengakibatkan trauma pada jaringan yang akan menyebabkan pelepasan mediator inflamasi sehingga menimbulkan nyeri yang poten. Semakin meningkatnya tindakan pembedahan akan semakin banyak pula orang yang mengalami nyeri akut akibat pembedahan. ${ }^{3}$ Menurut JCAHO (Joint Commision on Accreditation of Healthcare Organisations) pada tahun 2001, penilaian nyeri merupakan tanda vital kelima yang harus kita nilai pada setiap pasien. Penilaian nyeri yang teratur dan berulang harus dilakukan untuk menilai keadekuatan terapi analgesia yang sedang berjalan. Saat ini ada beberapa cara yang dapat digunakan untuk mengukur intensitas nyeri, yaitu: Verbal Analogue Scale, Verbal Numerical Analogue Scale, Visual Analogue Scale, dan Pain Relief Scale. Visual Analogue Scale (VAS) dan Skala Numerik Verbal (SNV) merupakan cara pengukuran nyeri yang sering digunakan pada penelitian yang berhubungan dengan nyeri setelah pembedahan karena mudah untuk diaplikasikan dan mudah dimengerti oleh pasien dengan tingkat pendidikan rendah. ${ }^{1,2}$

Proses melahirkan yang sekarang sering dilakukan yaitu seksio sesarea (SC) atas indikasi tertentu menjadi pilihan baik dokter maupun pasien. Proses melahirkan adalah suatu proses emosional dimana membutuhkan bonding antara ibu dan anak, sehingga mobilisasi ibu setelah dilakukan SC sangatlah penting. Pembiusan pada SC dilakukan dengan spinal anesthesia, epidural anesthesia, combine spinal and epidural anesthesia, dan pembiusan. ${ }^{12}$ Seorang dokter anestesi akan mempertimbangkan pilihan anestesi sesuai dengan kondisi ibu dan anak. Nyeri akut pascaoperasi yang tidak mendapat penanganan yang adekuat menimbulkan respon patologis yang muncul akibat aktivasi nosiseptor setelah trauma jaringan.

Selanjutnya akan terjadi aktivasi simpatoneural dan neuroendokrin yang berujung pada gangguan seperti, takikardia, hipertensi, hiperglikemia, imunosupresi, penurunan aliran darah regional atau stasis vena, dan agregasi trombosit. ${ }^{3}$ Nyeri pascaoperasi yang muncul pada saat istirahat biasanya sedang, rata- rata skala VAS antara 3 hingga 4 dari 10 selama 2-3 hari pertama pascaoperasi. Skor nyeri ini tetap muncul walaupun sudah mendapatkan terapi parenteral. Sementara itu, nyeri saat aktivitas, seperti batuk atau berjalan memiliki rata-rata skala VAS 7 hingga 8.15 Nyeri saat aktivitas bersifat sedang hingga berat bertahan selama beberapa hari hingga beberapa minggu berikutnya. ${ }^{4}$

Analgesi Lokal Infiltrasi adalah suatu teknik yang memberikan obat anestesi lokal yang diencerkan, dan diberikan adjuvant dari beberapa obat seperti Non Steroid Antiinflamatory Drugs (NSAID), epinephrine, dan opioid. Pemberian adjuvan dipilih sesuai dengan kondisi pasien, hal tersebut berkaitan juga dengan jalur penanganan nyeri yang dibutuhkan oleh seorang anestesiolog. Teknik pemberian obatobatan disebut multimodal local infiltration analgesia. ${ }^{6}$ Pemberian Local Infiltration Analgesia (LIA) pada pasien setelah menjalani SC akan dapat mengurangi kebutuhan opioid. ${ }^{8}$

Obat-obat lokal anestesi yang pada akhirnya diserap secara sistemik dapat mempengaruhi jumlah sekresi Air Susu Ibu (ASI), namun tidak terdokumentasi membawa pengaruh terhadap proses menyusui. ${ }^{5}$ Opioid memiliki efek samping pada produksi ASI ibu dan pada foto kontras yang dilakukan pada pasien yang menerima morphin dan pethidine terdapat transfer ke produksi ASI sehingga dapat menyebabkan sedasi pada bayi. Pasien yang diberikan LIA diharapkan dapat mengurangi nyeri dan hal ini sangat bermanfaat pada mobilisasi ibu, proses menyusui, mengurangi postnatal depresssion. ${ }^{5}$ Tujuan penelitian ini adalah untuk mengetahui apakah teknik LIA dapat menurunkan skala VAS dalam 24 jam pascaoperasi SC dibandingkan pemberian parasetamol intravena dalam 24 jam pascaoperasi SC. Selain itu, untuk mengetahui teknik LIA sebagai analgesia pascaoperasi dapat menurunkan kebutuhan analgetik dalam 24 jam pascaoperasi SC dibandingkan pemberian parasetamol intravena dalam 24 jam pascaoperasi SC. 


\section{Metode}

Desain penelitian ini adalah studi intevensi. Penelitian dilakukan di RSUD Mgr. Gabriel Manek, SVD Atambua dan dilakukan sejak bulan Februari 2018-April 2018. Populasi penelitian adalah pasien wanita yang hamil. Sampel penelitian ini adalah pasien wanita yang hamil dan akan menjalankan SC. Subjek penelitian ini adalah wanita hamil yang direncanakan SC dengan status ASA I atau ASA II dan sudah menyetujui untuk terlibat dalam penelitian. Kriteria inklusi adalah pasien yang bersedia di lakukan tindakan anestesi dengan regional anestesi, bersedia untuk menjadi peserta penelitiandandibuktikandenganpenandatanganan surat persetujuan yang telah disiapkan peneliti, masuk dalam indikasi regional anestesi, ibu hamil yang akan direncanakan SC rentang usia antara 19-45 tahun, pasien tidak memiliki kontra indikasi terhadap Anti Inflamasi Non Steroid (AINS), dan pasien dengan status fisik ASA I-II.

Kriteria eksklusi antara lain pasien yang sedang menderita atau memiliki riwayat penyakit tertentu sehingga menyebabkan terjadinya gangguan pada fungsi hepar dan ginjal, seperti misalnya karsinoma hepatoseluler, hepatitis yang disebabkan oleh karena infeksi virus maupun obat- obatan, sirosis hepatis, Chronic Kidney Disease, dan Acute Kidney Injury, pasien dengan gejala peningkatan tekanan darah akibat kehamilan seperti PEB dan eklampsia, pasien dengan kondisi bayi mengalami kegawatan, pasien memiliki kontra indikasi terhadap obat obatan anestesi yang digunakan dalam penelitian ini, skor Bromage $\geq 2$ atau Skor Aldrete $<9$ saat di ruang pemulihan lebih dari 2 jam. Variabel dependen yaitu intervensi LIA atau Parasetamol dan intensitas nyeri yang diukur dengan VAS setelah Skor Bromage $<2$ atau Skor Aldrette $\geq 9$ (selanjutnya disebut sebagai VAS 0 dan intensitas nyeri yang diukur dengan VAS 24 jam setelah VAS 0 (selanjutnya disebut VAS (24). Variabel independen yaitu waktu pengukuran Skor Bromage $<2$ atau Skor Aldrete $\geq 9$ disebut sebagai jam ke 0 dan 24 jam setelahnya.

Sampel dibagi menjadi dua kelompok, yaitu: pasien di kelompok dengan LIA akan mendapatkan tindakan LIA berupa campuran (cocktail) lidocaine $0,5 \%+$ ketorolac $30 \mathrm{mg}+$ normal saline dengan total cairan $20 \mathrm{~mL}$, untuk kelompok pasien yang tidak mendapatkan LIA diberikan analgetik pascaoperasi parasetamol sebesar $15-25 \mathrm{mg} / \mathrm{kgBB}$ tiap 6 jam. Teknik pemberian LIA dilakukan pada saat akhir operasi dimana proses penutupan otot akan dilakukan injeksi pada otot sebanyak $10 \mathrm{~mL}$ cairan cocktail, lalu setelah penjahitan kulit dilakukan penyuntikan cairan cokctail sebanyak $10 \mathrm{~mL}$ pada subkutis. Proses penyuntikan ini akan dilakukan oleh operator dalam hal ini spesialis obstetrik dan ginekologi. Gambar 2.1a dan 2.1b menunjukkan teknik pemberian LIA secara subkutis. Kelompok pasien yang tidak mendapatkan LIA akan diberikan parasetamol intravena saat tiba di ruang pemulihan, lalu setelah 6 jam kemudian akan diberikan parasetamol intravena tiap 6 jam di ruangan rawat inap selama 24 jam. Pasien dipindahkan ke ruangan rawat inap dengan Skor Bromage $<2$ atau Skor Aldrette $\geq 9$, dan sebelum pindah ruangan dilakukan pengukuran nyeri dengan VAS dan Wong Baker FACES. Dua puluh empat jam pertama pascaoperasi di ruang rawat inap dilakukan pengukuran ulang nyeri dengan VAS dan Wong Baker FACES. Kriteria yang digunakan untuk memulai pengukuran intensitas nyeri adalah skor Bromage atau Skor Aldrette. Skor Bromage $<2$ atau Skor Aldrete $\geq 9$ merupakan kondisi pasien sudah dalam keadaan sadar penuh sehingga mampu menerima instruksi maka pengukuran terhadap intensitas nyeri mulai dikerjakan. Pengukuran derajat nyeri dengan menggunakan VAS karena nilai VAS berkorelasi baik dengan SVN maka teknik pengukuran derajat nyeri dilakukan dengan cara meminta pasien menentukan derajat nyeri yang dialami mulai dari angka 0 (tidak nyeri) sampai dengan 10 (nyeri hebat yang tak terbayangkan). Nilai VAS ditentukan dengan meminta pasien menandai skala yang terdapat pada penggaris VAS dan kemudian dikonfirmasikan dengan kondisi obyektif yang dilihat dari wajah pasien dan disesuaikan dengan gambar skala nyeri sesuai dengan skala Wong Baker Faces. Pasien mendapatkan "analgetic rescue", apabila didapatkan VAS lebih dari $>6$, dengan fentanyl $0 .-1 \mathrm{mcg} / \mathrm{kgBB}$. Untuk sampel 
yang mendapatkan obat analgesik tambahan, akan dilakukan pencatatan nilai VAS, jam pemberian obat, dan dosis obat yang diberikan. Metode statistik yang digunakan pada penelitian ini adalah uji korelatif dengan menggunakan uji Chi-Square untuk mengetahui pengaruh LIA dan paracetamol terhadap VAS 0 dan VAS 24. Lalu, dilakukan uji Spearman untuk mengetahui intervensi LIA atau parasetamol yang lebih efektif.

\section{Hasil}

Pada Tabel 3.1 tampak jumlah sampel yang mendapatkan intervensi LIA dan Parasetamol sebagai manajemen nyeri pascaoperasi SC. Pada Tabel 3.2 tampak jumlah sampel dengan intervensi LIA dan Parasetamol yang mendapatkan Analgesic Rescue (AR). Tabel 3.4 menunjukkan hasil tabel silang (crosstabs) bahwa dari 35 orang pasien yang diberi intervensi paracetamol pada jam ke- 0 , ada sebanyak 18 orang yang mempunyai skor VAS 0,9 orang mempunyai skala VAS 1,7 orang mempunyai skala VAS 2, dan 1 orang lainnya mempunyai skala VAS 4. Adapun dari 35 orang pasien yang diberi intervensi LIA pada jam ke-0, 19 orang mempunyai VAS 0,13 orang mempunyai VAS 1 , 3 orang mempunyai skala VAS 2 , dan tidak ada yang mempunyai skala VAS 4.

Berdasarkan hasil pengujian dengan Chi-Square dari Tabel 3.5 menunjukkan nilai sebesar 3.354, dengan nilai signifikansi (p) sebesar 0.340 yang lebih besar dari alpha 0.05 , sehingga Ho diterima, dan dapat disimpulkan bahwa pada jam ke-0, pemberian parasetamol dan LIA belum memberikan pengaruh yang signifikan (bermakna) terhadap skala VAS pasien. Uji korelasi Spearman untuk mengetahui adanya hubungan antara pemberian paracetamol dan LIA dengan VAS pada jam ke-0 dapat dilihat pada Tabel 3.6. Dari hasil uji korelasi menunjukkan bahwa pemberian antara parasetamol dan LIA dengan VAS pada jam ke-0 mempunyai nilai koefisien korelasi sebesar -0.090 dengan nilai signifikansi sebesar 0.459 yang lebih besar dari alpha 0.05 , sehingga terima Ho dan dapat disimpulkan bahwa tidak ada hubungan yang signifikan antara pemberian parasetamol dan LIA dengan VAS pada jam ke0 . Artinya pada jam ke- 0 , tinggi rendahnya skala VAS pasien tidak dipengaruhi oleh pemberian parasetamol dan LIA.

Adanya kaitan antara pemberian paracetamol dan LIA denganVAS pada jam ke 0 dapat digambarkan dalam bentuk histogram Gambar 3.1. Pada Tabel 3.6 terlihat bahwa dari 35 orang pasien yang diberi intervensi parasetamol pada jam ke-24, ada sebanyak 25 orang yang mempunyai VAS 2 , dan 10 orang lainnya mempunyai VAS 3 . Adapun dari 35 orang pasien yang diberi intervensi LIA pada jam ke-24, ada sebanyak 5 orang yang mempunyai VAS 0,19 orang mempunyaiVAS 1 , 9 orang mempunyai VAS 2, dan 2 orang lainnya mempunyai skala VAS 4.

Berdasarkan hasil pengujian dengan Chi-Square di Tabel 3.5 menunjukkan nilai sebesar 36.863, dengan nilai signifikansi (p) sebesar 0.000 yang

Tabel 3.2. Crosstabs antara Kelompok Intervensi dengan VAS jam ke-0

\begin{tabular}{|c|c|c|c|c|c|c|c|}
\hline \multicolumn{8}{|c|}{ Kelompok Intervensi * VAS $(0)$ Crosstabulation } \\
\hline & & & & & Vas & & Total \\
\hline & & & Skor1 & Skor 2 & Skor 3 & Skor 4 & \\
\hline \multirow[t]{2}{*}{$\begin{array}{l}\text { Kelompok } \\
\text { intervensi }\end{array}$} & Parasetamol & $\begin{array}{l}\text { Count } \\
\text { of } \% \text { of } \\
\text { total }\end{array}$ & $1825,7 \%$ & $912,9 \%$ & $710,0 \%$ & $11,4 \%$ & $3550,0 \%$ \\
\hline & LIA & $\begin{array}{l}\text { Count } \\
\text { of } \% \text { of } \\
\text { total }\end{array}$ & $1927,1 \%$ & $1318,6 \%$ & $34,3 \%$ & $00 \%$ & $3550.0 \%$ \\
\hline Total & & $\begin{array}{l}\text { Count } \\
\text { of } \% \text { of } \\
\text { total }\end{array}$ & $3752.9 \%$ & $2231,4 \%$ & $1014.3 \%$ & $11 ' 4 \%$ & $70100,0 \%$ \\
\hline
\end{tabular}




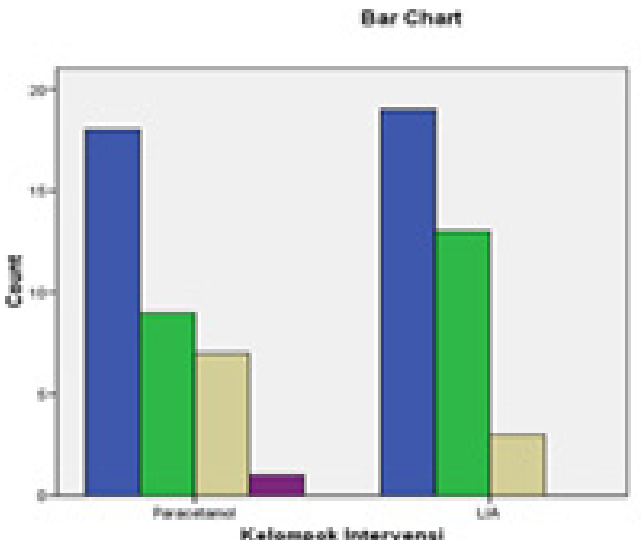

Gambar 3.1. Histogram antara Kelompok Intervensi dengan VAS jam ke-0.

lebih kecil dari alpha 0.05. Sehingga Ho ditolak, dan dapat disimpulkan bahwa pada jam ke-24, pemberian parasetamol dan LIA memberikan pengaruh yang signifikan (bermakna) terhadap VAS pasien, dimana pemberian intervensi LIA lebih baik dalam menurunkan VAS pasien
Tabel 3.3. Hasil Uji Chi-square antara Kelompok Intervensi (LIA dan Parasetamol) dengan VAS jam ke-0.

\begin{tabular}{ll}
\multicolumn{2}{l}{ Chi-Square Tests } \\
Value Df $\quad \begin{array}{l}\text { Asymp.Sig. } \\
\text { (2-sided })\end{array}$
\end{tabular}

\begin{tabular}{|c|c|c|c|}
\hline $\begin{array}{l}\text { Pearson Chi- } \\
\text { Square }\end{array}$ & $3.354 \mathrm{a}$ & 3 & .340 \\
\hline $\begin{array}{l}\text { Likehood } \\
\text { Ratio }\end{array}$ & 3.790 & 3 & .285 \\
\hline $\begin{array}{l}\text { Linear-by- } \\
\text { linearAsso- } \\
\text { ciation }\end{array}$ & 1.321 & 1 & .250 \\
\hline $\begin{array}{l}N \text { of Valid } \\
\text { Cases }\end{array}$ & 70 & & \\
\hline
\end{tabular}

Keterangan: a. 2 cells $(25.0 \%)$ have expected count less than 5 . The minimum expected count is .50.

dibandingkan dengan pemberian intervensi Tabel 3.6 menunjukkan adanya hubungan antara pemberian parasetamol dan LIA dengan VAS

Tabel 3.4. Crosstabs Kelompok Intervensi (LIA dan Parasetamol) dengan VAS jam ke-24

Kelompok Intervensi * VAS (0) Crosstabulation

\begin{tabular}{|c|c|c|c|c|c|c|c|}
\hline & \multicolumn{4}{|c|}{ VAS $(0)$} & \multirow[b]{2}{*}{ Total } \\
\hline & & & Skor 0 & Skor 1 & Skor 2 & Skor 4 & \\
\hline \multirow{4}{*}{$\begin{array}{l}\text { Kelompok } \\
\text { Intervensi }\end{array}$} & Paracetamol & Count & $\overline{18}$ & $\overline{9}$ & 7 & $\overline{1}$ & 35 \\
\hline & & $\%$ of Total & $25.7 \%$ & $12.9 \%$ & $10.0 \%$ & $1.4 \%$ & $50.0 \%$ \\
\hline & LIA & Count & 19 & 13 & 3 & 0 & 35 \\
\hline & & $\%$ of Total & $27.1 \%$ & $18.6 \%$ & $4.3 \%$ & $.0 \%$ & $50.0 \%$ \\
\hline \multirow[t]{2}{*}{ Total } & & Count & 37 & 22 & 10 & 1 & 70 \\
\hline & & $\%$ of Total & $52.9 \%$ & $31.4 \%$ & $14.3 \%$ & $1.4 \%$ & $100.0 \%$ \\
\hline
\end{tabular}

Tabel 3.5. Hasil uji Chi-square antara kelompok intervensi (LIA dan Paracetamol) dengan VAS jam ke-24

\section{Chi-Square Tests}

\begin{tabular}{|l|r|r|r|}
\hline & \multicolumn{1}{|c|}{ Value } & df & $\begin{array}{c}\text { Asymp. Sig. } \\
\text { (2-sided) }\end{array}$ \\
\hline Pearson Chi-Square & $36.863^{\circ}$ & 3 & .000 \\
Likelihood Ratio & 46.928 & 3 & .000 \\
Linear-by-Linear & 28.790 & 1 & .000 \\
Association & 70 & & \\
N of Valid Cases & & & \\
\hline
\end{tabular}

a. 2 cells $(25.0 \%)$ have expected count less than 5 . The minimum expected count is 2.50 . pada jam ke-24. Berdasarkan hasil uji korelasi di atas menunjukkan bahwa antara pemberian paracetamol dan LIA dengan VAS pada jam ke24 mempunyai nilai koefisien korelasi sebesar -0.671 dengan nilai signifikansi sebesar 0.000 yang lebih besar dari alpha 0.05 , sehingga tolak Ho dan dapat disimpulkan bahwa ada hubungan yang signifikan antara pemberian parasetamol dan LIA dengan VAS pada jam ke- 24. Artinya pada jam ke-24, pemberian intervensi LIA dapat lebih menurunkan VAS pasien dibandingkan dengan pemberian intervensi parasetamol. 
Tabel 3.6. Uji Spearman antara Kelompok Intervensi (LIA dan Parasetamol) dengan VAS jam ke-24

Symmetric Measures

\begin{tabular}{|c|c|c|c|c|}
\hline & Value & $\begin{array}{l}\text { Asymp. } \\
\text { Std. Error }\end{array}$ & Approx. $T^{b}$ & Approx. Sig. \\
\hline $\begin{array}{l}\text { Ordinal by Ordinal Spearman Correlation } \\
\mathrm{N} \text { of Valid Cases }\end{array}$ & $\begin{array}{r}-.671 \\
70\end{array}$ & .072 & -7.460 & $.000^{\circ}$ \\
\hline
\end{tabular}

a. Not assuming the null hypothesis.

b. Using the asymptotic standard error assuming the null hypothesis.

c. Based on normal approximation.

\section{Pembahasan}

Adanya kaitan antara pemberian parasetamol dan LIA dengan VAS pada jam ke- 24 dapat digambarkan dalam bentuk histogram pada gambar 3.1. Berdasarkan gambar diagram tersebut menunjukkan bahwa terdapat kecenderungan yang jelas, dimana pada jam ke-24, pemberian intervensi LIA dapat lebih menurunkan VAS pasien dibandingkan dengan pemberian intervensi paracetamol. Pada penelitian ini analgetika infiltrasi lokal diberikan adjuvant ketorolac sebesar $30 \mathrm{mg}$, ketorolac memiliki peran dalam menghambat produksi mediator eicosanoid pada perifer dan menghambat respon kerusakan jaringan. ${ }^{6,8}$ Sintesis eicosanoid diinisiasi oleh aktivasi fosfolipase A2 dan pelepasan asam arakhidonat dari membran fosfolipid. Selanjutnya asam arakhidonat akan diubah dalam jalur siklooksigenase (COX) dan lipoksigenase (LO) menjadi prostaglandin, tromboksan, dan leukotrien. ${ }^{13}$ Disini peran ketorolac dalam memberikan efek analgesik lokal. ${ }^{13}$

Pada penelitian ini terdapat dua kelompok, yang mendapatkan LIA dan kelompok parasetamol sebagai manajemen nyeri pasca operasi. Penulis mencatat pada kelompok LIA dari 35 pasien, terdapat 22 pasien $(61 \%)$ yang dapat melakukan mobilisasi duduk dalam waktu kurang dari 12 jam pasca operasi, sementara itu terdapat 13 pasien (39\%) yang baru bisa melakukan mobilisasi duduk lebih dari 12 jam pasca operasi. Pada kelompok paracetamol dari 35 pasien terdapat 8 pasien $(22 \%)$ yang dapat melakukan mobilisasi duduk dalam kurun waktu kurang dari 12 jam pasca- operasi, dan terdapat 27 pasien (78\%) yang tidak dapat melakukan mobilisasi kurang dari 12 jam bahkan beberapa pasien baru mulai mobilisasi pada 24 jam pasca operasi.

Proses melahirkan adalah suatu proses emosional dimana membutuhkan bonding antara ibu dan anak, sehingga mobilisasi ibu setelah dilakukan SC sangatlah penting dalam proses menyusui 7, penulis mencatat bahwa terdapat perbedaan antara dua kelompok tersebut. Pada kelompok LIA, dari 35 pasien terdapat 20 pasien $(57 \%)$, yang dapat menyusui bayinya kurang dari 3 jam pasca operasi, selebihnya 15 pasien baru dapat menyusui bayinya lebih dari 3 jam pascaoperasi, hal tersebut ada yang di karenakan bayi dalam kondisi yang belum layak di lakukan rawat gabung bersama ibu. Pada kelompok parasetamol, dari 35 pasien terdapat 16 pasien $(61 \%)$ yang dapat menyusui bayi kurang dari 3 jam pascaoperasi, selebihnya 19 pasien $(39 \%)$ baru dapat menyusui bayi lebih dari 3 jam pascaoperasi, yang hal tersebut bisa juga dikarenakan kondisi bayi belum layak rawat gabung bersama ibu. Opioid memiliki efek samping pada produksi ASI ibu dan pada foto kontras yang dilakukan pada pasien yang menerima morphin dan pethidine terdapat transfer keproduksi ASI sehingga dapat menyebabkan sedasi pada bayi. ${ }^{10,11}$ Pada penelitian ini penulis juga mencatat kebutuhan analgetik dalam 24 jam pasca operasi, pada kelompok LIA tercatat tidak ada pasien yang membutuhkan analgetik rescue selama 24 jam pascaoperasi, dan pada kelompok parasetamol tercatat terdapat 1 pasien yang membutuhkan analgetic rescue (VAS 4) dalam 24 jam pertama. 


\section{Simpulan}

Pemberian LIA dapat menurunkan VAS dalam 24 jam pasca operasi SC dibandingkan dengan pemberian parasetamol intravena. Pemberian LIA dapat mengurangi kebutuhan analgetik dalam 24 jam pascaoperasi SC dibandingkan dengan pemberian parasetamol intravena.

\section{Daftar Pustaka}

1. Marsaban AHM, Bagianto H, Maas EM. Mekanisme dan Patofisiologi Nyeri, Panduan dan Tatalaksana Nyeri Perioperatif. Perhimpunan Dokter Spesialis Anestesiologi dan Reanimasi Indonesia, 2009: 1-9.

2. Hines RL, Usman RD, Vadivelu N. Essential of Pain Management. Springer, 2011: 651-n 55.

3. Christopher LW, Srinivasa NR. Treatment of acute postoperative pain. The Lancet. 2011; 377 (9784): 2215-25.

4. Brennan TJ.Pathophysiology of postoperative pain. 2011;152 (3): 33-40.

5. Bamigboye AA, Hofmeyr GJ. Caesarean section wound infiltration with local anaesthetic for postoperative pain relief any benefit?. South African Medical Journal. 2010: 100 (5).

6. Nilesh PB. Guide to Pain Management in Low-Resource Settings: Physiology of Pain. International Association for the Study of Pain. 2010. Chapter 3: 13-17.

7. Apfelbaum.Anesthesia for Cesarean Delivery. In: Palmer, Craig M, eds. Anesthesia for Cesarean Delivery in Obstetric Anesthesia. New York. Oxford University Press, 2012: 79-155.
8. Clare B, Colin RP. Anatomy, physiology, and pharmacology of pain. Anaesthesia and Intensive Care Medicine. 2013; 14 (11): 482 83.

9. Longnecker, Watkins LR. Pathological and Protective Roles of Glia in Chronic pain. Neuroscience. 2010 Volume: 10: 23-36.

10. Barash PG, Cullen BF, Stoelting RK, Cahalan MK, Stock MC, Ortega R. Clinical Anesthesia. 7th edition. 2013. Philadelphia. Lippincott Williams \& Wilkins.

11. Ritter JM, Lewis LD, Mant TGK, Ferro A. A Textbook of Clinical Pharmacology and Therapeutics. 5th edition. 2008. London, Hodder Education.

12. Morgan EG Jr, Mikhail MS, Murray MJ. Clinical Anesthesiology. 4th Edition. 2006. United State. McGraw-Hill Companies, Inc.

13. Khanapure SP, Garvey DS, Janero DR, Letts LG. Eicosanoids in inflammation: biosynthesis, pharmacology, and therapeutic frontiers. Curr Top Med Chem. 2007; 7(3): 311-40.

14. Graham GG, Davies MJ, Day RO, Mohamudally A, Scott KF. The modern pharmacology of paracetamol: therapeutic actions, mechanism of action, metabolism, toxicity, and recent pharmacological findings. Inflammopharmacology. 2013; 21: 201-232.

15. De Oliveira, GS JR, Castro-Alves, LJ, McCarthy RJ. Single-dose systemic acetaminophen to prevent postoperative pain: A meta-analysis of randomized controlled trials. The Clinical Journal of Pain. 2015; 31 (1): 86-93. 